\title{
Implementation of Good University Governance Policy in State Islamic Institute (IAIN) in Indonesia
}

\author{
Sulkhan Chakim \\ State Islamic Institute, Dakwah Faculty, Purwokerto, Middle Java, Indonesia \\ Email address: \\ sulkhan@iainpurwokerto.ac.id \\ To cite this article: \\ Sulkhan Chakim. Implementation of Good University Governance Policy in State Islamic Institute (IAIN) in Indonesia. International \\ Journal of Education, Culture and Society. Vol. 4, No. 1, 2019, pp. 19-27. doi: 10.11648/j.ijecs.20190401.13
}

Received: February 18, 2019; Accepted: April 4, 2019; Published: May 7, 2019

\begin{abstract}
Good University Governance (GUG) is a concept adopted from Good Corporate Governance (GCG). At present, the study of Corporate Governance is a concept that has been implemented by large companies and is not a new issue when compared to the issue of University Governance, because previous studies on Good University Governance are still poorly publicized. The study of University Governance is not preceded by an important event about the bankruptcy of a college. Some researchers argue that Corporate Governance plays an important role in the supervision of companies related to corruption and bankruptcy cases. Likewise, the study of university governance makes an important contribution to the managers of higher education as one of the references in managing higher education institutions. This study asks how the policy implementation in the IAIN environment is from the perspective of Good University Governance (GUG). The approach used in this study is qualitative, namely interviews and documentation as data collection techniques. Meanwhile, the sample is a number of leading sectors in the State Islamic Institute in Indonesia. The scope of the results of this study on non-academic covers three fields, namely the financial reporting system and financial performance standardization have not been conducted by a review, human resource management has not been reviewed and standardized performance and work performance, and management of State Property.
\end{abstract}

Keywords: Implementation, Policy, Good University Governance (GUG), and IAIN (State Islamic Institute)

\section{Introduction}

Indonesia as a developing country facing the global financial crisis will greatly affect Indonesia's economic condition and one of the effects of the global financial crisis is the slowdown in Indonesia's economic growth in 2008. Indonesia's overall economic growth reached $6.1 \%$ in 2008 or slightly lower than the year 2007 amounted to $6.3 \%$ [1]. The crisis became a problem for foreign investors to withdraw the capital they had invested. This is very detrimental because Indonesia is one of the developing countries whose funds are needed by foreign investors. Furthermore, Indonesia's economic situation and competitiveness in the last ten years have increased; Indonesia's economy in 2017 grew 5.07\% explained by Minister of Finance Sri Mulyani that in the past decade, Indonesia's economic growth had stable durability in the midst of world economic turmoil [2].

The practice of Corruption, Collusion and Nepotism
(KKN) has become a cause of distrust and abandonment by foreign investors. In addition, also because many companies in Indonesia have not consistently applied Good Corporate Governance (GCG). GCG practices can help improve the company's image by improving financial performance, as well as reducing negative risks [3]. Good University Governance (GUG) is a concept adopted from Good Corporate Governance (GCG). At present, the study of Corporate Governance is a concept that has been implemented by large companies and is not a new issue when compared to the issue of University Governance, because previous studies on Good University Governance are still poorly publicized. Issues and studies on Corporate Governance have caught the attention of corporate CEOs since the 1990s and became very popular after the collapse of Enron and World.com in the early 2000s. In line with Indonesia's economic journey over the past ten years, Indonesia's competitiveness rankings have risen to 45 . This ranking is said to be quite encouraging, President Joko 
Widodo's government made a number of efforts to improve Indonesia's competitiveness, including infrastructure development and business ease improvements [4]. As with the study of Corporate Governance, the study of University Governance was not preceded by an important event about the bankruptcy of a college. Some researchers argue that Corporate Governance plays an important role in corporate supervision [5].

The study of university governance makes an important contribution to the managers of higher education as one of the references for managing higher education [6]. Discussions about GCG or GUG are certainly not separate from the issue regarding participation in the practice of the budgeting process. This practice is an accountability activity in the management control system and has been the subject of cross-cultural testing. The relationship between participatory budgeting and managerial performance has long been an important issue in organizational research. Along with the management of universities in Indonesia that are continuously being improved. In the context of ranking universities in Indonesia, the position of higher education institutions has deteriorated in the eyes of the world based on QS world university ranking conducted in 1000 of the best universities from 84 countries. which is ranked 277th. The Bandung Institute of Technology (ITB) was ranked 359th. This ranking declined 28 positions from the previous year which was in 331st place. Meanwhile, Universitas Gajah Mada (UGM) is ranked 391. Increased from the previous year in the range 401-410 [7]. This deterioration position was questioned by President Joko Widodo about the performance of the Ministry of Research and Technology officials; so that the chancellors are able to make a breakthrough quickly [8].

The most urgent demand for spurring the development of quality and relevant education is to increase capacity in conducting policy analysis. Policy analysts in the field of education are not only required to master research and development techniques, but are also required to master relevant educational issues, both internal education issues, and educational issues in a cross-sectoral context. Internal education issues will include the education system and its integral components, such as the issue of "equity, and expansion of access to education, issues of improving quality, relevance and competitiveness of education, and issues of strengthening governance, accountability and public imaging" Three issues this, becomes the main issue of the education system today in the strategy of developing the education system. Efforts to achieve these educational goals are carried out by the government through the implementation of various policies, including policies in the education sector. The policy is a compass or guideline to achieve predetermined goals [9]. According to Milliken and Colohan, a manifestation of government belief that public services should be managed in accordance with the same criteria as any other economic undertaking. The main effects of this reform on higher education are increased pressure for more accountability, changes in structure and funding, increased student numbers and an intense exposure to market forces [10].

Some important aspects of accountability, structural change, and finance or budget, increasing the number of students and the intensity of publications to the market must be considered by the leaders of higher education institutions. Based on the background above, this research was conducted to analyze the application of GUG carried out in accordance with the management procedures and principles of GUG, as well as reviewing the implementation of GUG which had an impact on universities to improve performance and be more transparent about institutional operations.

\section{Methodology}

The paradigm of this research is qualitative-descriptive. Descriptive format tries to describe, summarize various conditions, various changes or various variables that arise in the community to be the object of research [20]. Explanation of the characteristics discussed, and examined various aspects in certain phenomena [21].

The object of this research is the implementation of policies in the State Islamic Institute (IAIN) of Purwokerto in the perspective of Good University Governance. Meanwhile, primary sources were extracted from the results of interviews with prominent officials in the IAIN purwokerto sector. Related to this with the theme and subject matter contained here also need to be done, so that it can make it easier to carry out the analysis. Secondary sources were used from comments or critical notes and views of SPI officials from several heads of UIN and IAIN SPI, as well as experts in Higher Education Management. This source is extracted from articles that examine the implementation of policies in universities.

To get the data needed in this study, use interviews and comparative studies to other universities. Interviews were used to explore primary data obtained from leading sectors in the IAIN Purwokerto Environment. The data analysis technique in this study is to do three steps, namely data reduction, data presentation and completion of conclusions. While the validity of the data using triangulation data analysis techniques. The triangulation method used is source triangulation.

\section{Leterature Review}

Changes in behavior in an organization are needed to support healthy organizations in various levels of management. [11] "an integrated management philosophy, it is associated with cultural values that promote human thought and enhance collaboration". Cultural values will encourage individual thinking and develop collaboration. Because the cultural value of the organization is the key to putting cultural values at the core of the organization. In the context of change, according to Sallis [12], organizational culture requires a change in attitude and ways of working. Although both are targeted, a change in organizational governance is an essential requirement. This means that 
employees need the comfort of the organization's environment, encouragement and the introduction of their successes and achievements. Besides that, policies that emphasize increasing employee motivation in the effectiveness of their work are important elements in the organization, such as training, job enrichment, career development and work environment [13].

In this context, the government is very interested in the management standard so that it can carry out supervision and there are no various irregularities. The discussion about GCG or GUG is certainly not separate from the issue regarding participation in the budgeting process. This practice is an accountability activity in the management supervision system and has been the subject of cross-cultural testing. In the context of cross-cultural communication, culture shapes the perceptions of individuals and groups in an organization related to individual identity and history or related experiences, how they are present and guide others or often called impression management [14]. A job that is not easy is to control others completely, but group interaction plays an important role in how identity is developed and actualized. Identity is understood as an effort to build individual characteristics, beliefs, knowledge, and abilities to define oneself [15]. One important instrument for building cohesiveness is the identity of individuals in group relations becomes significant, a way that is widely developed is teamwork because it will encourage improvements quickly, and develop new ideas and motivate colleagues [16]. In this context, the similarity of identity in groups is one of the important factors in achieving the organization's vision that can drive the work culture of the organization.

Work culture is the most important concept for building organizational health and productivity. Because this concept is reviewed through organizational functions, among others: a) Equating the mindset in basic values, perceptions and work attitudes. b) Growing multiple awareness (creativity, taste, intention, and spirituality). c) Establish correct and good behavior. d) Turning personal culture into a collective culture [17]. In the non-academic context, budget management activities cannot be separated from the governance activities of an organization, with the concept of good governance, good university governance is relevant to the principles of Good Corporate Governance (GCG). These principles include transparency, accountability, responsibility, independence, and justice. The GCG principle can be applied to manage a college [6]. Good governance also provides a structure that can facilitate the determination of organizational goals, as well as a means to determine managerial performance monitoring techniques [18]. In the New managerialism concept is based on economic relations, efficiency, and effectiveness that cannot be separated from the concepts of standardization, specialization, selection, and autonomy to be an essential part of an organization or college [10]. The university is seen as a living organism, standing in broad symbolic relations with the surrounding community [19], as stated by Dušan Lesjak, that "Due to the development of the HE system in recent years, increasing number of participating people in it and consequently growing financial needs on the one hand, and limited public funding on the other, the efficiency of the use of funding has become very important "[20]. Increased workgroup participation in an organization will be directly proportional to growing financial needs and efficiency is an important concept for the existence of the organization.

The paradigm of this research is qualitative-descriptive. The descriptive format aims to describe, summarize various conditions, various situations or various variables that arise in the community to be the object of research [21]. Explanation of the characteristics of the subject under study, and studied various aspects in certain phenomena [22].

The object of this research is the implementation of policies in the State Islamic Institute (IAIN) of Purwokerto in the perspective of Good University Governance. Meanwhile, the primary source that was extracted came from the interviews of the leading sector IAIN Purwokerto case, in this case the identification of the theme and subject matter contained in it also needs to be done, so that it can make it easier to carry out the analysis. Secondary sources used came from comments or critical notes and views of several SPI officials from several heads of UIN and IAIN SPI, as well as experts in Higher Education Management. This source is extracted from articles that examine the implementation of policies in universities.

To obtain the data needed in this study is to use interviews and comparative studies to other universities. Interviews were used to explore primary data obtained from the leading sector in the Purwokerto IAIN environment. The data analysis technique in this study is to do three steps, namely data reduction, data presentation, and conclusion drawing. While the validity of the data using triangulation data analysis techniques. The triangulation method used is source triangulation.

\section{Results and Discussion}

\subsection{Leadership Patterns Based on Spirituality}

Leadership is an essential concept in an organization in any organization, as well as in a college. Leadership will affect the organizational environment, as follows: An organizational environment is defined as the sum total of people, institutions, and activities that exist outside of the organization's boundaries but exert actual or potential influence over the company's internal operations [16]. In the context of leadership at IAIN Purwokerto, it was like several interviews, I position employees as work partners. Examples can be seen from the command sentences that are not "pitched", but by "asking for help". This will be more acceptable to employees, and employees can do every job sincerely [23].

The way to communicate between individuals with a smoother language and not with the type of command can encourage motivated subordinates to do more energetic tasks. In other words, the use of language with the intention of 
asking for "help" felt by his subordinates is a form of respect for his existence. They feel happy and comfortable in completing work every day. Feelings of pleasure and unhappiness are the basis for doing work and how to respond to work in the environment. In the context of resource development can improve work performance, especially in commitment, motivation, and job satisfaction [24].

Employee commitment is built in several ways, namely 1) regular group development as a forum for evaluation and motivation in each work unit. 2) a record of the presence of face print every day and the recap. 3) Daily performance reporting [23]. This fact is still a weakness in conducting

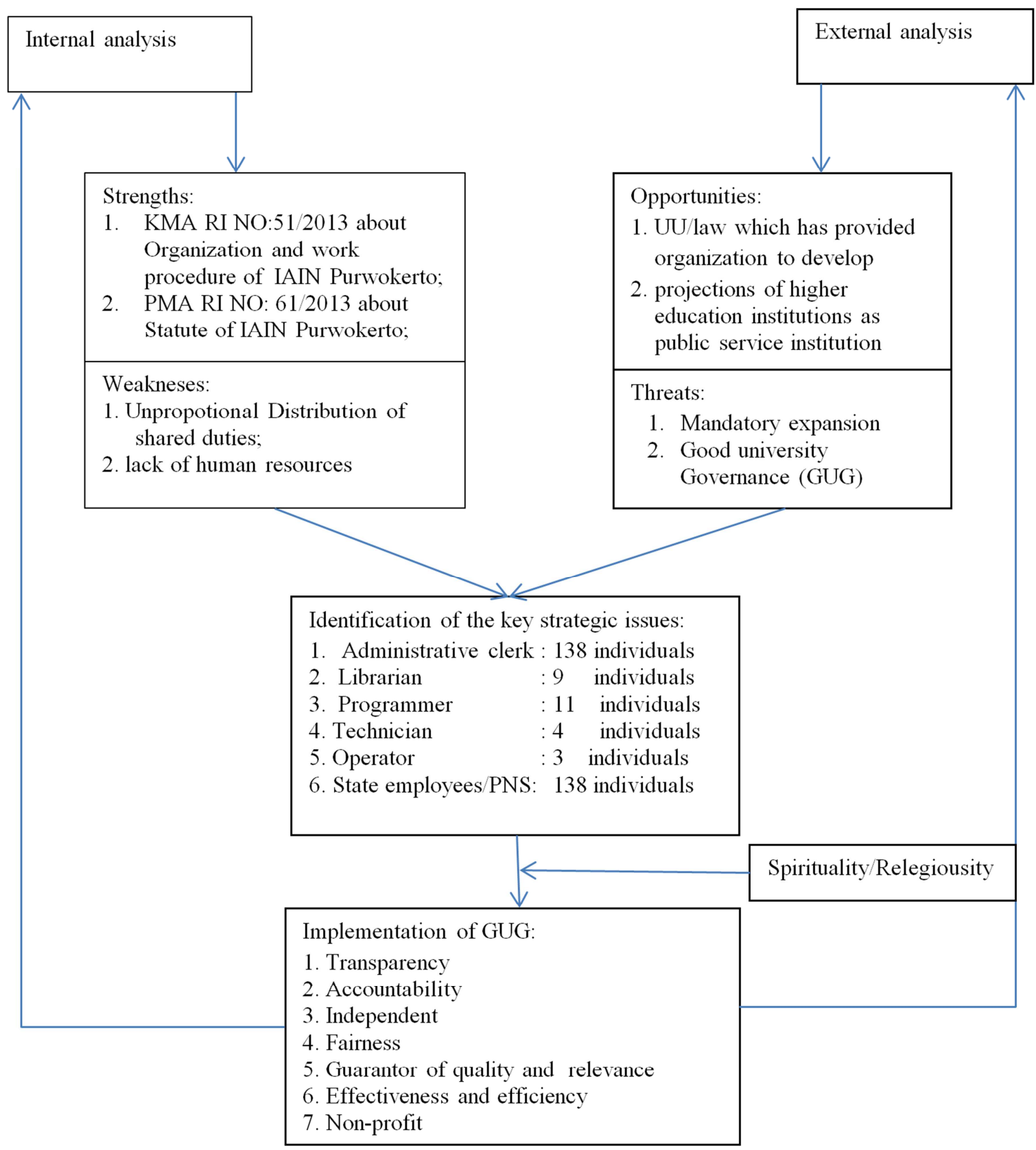

Figure 1. Institutional situation.

\subsection{The System Programm}

The IAIN strategic activity program refers to the Ministry evaluations because the work control system is based online and is based on the workload of each unit. This factuality must get attention from the leaders of the IAIN higher education because in the IAIN environment in Indonesia this governance system has not received serious attention. IAIN as a religious college, religious or spiritual aspect should be used as a dominant cultural base because the awareness of spirituality arises from within a person which influences one's perceptions and behavior [17]. This aspect of spirituality has not been used as a basis for improving performance in the organizational environment. of Religion Strategic Plan. Plans are needed by each organization of any kind. Without planning, the program of 
activities as an activator of the organization will take place randomly, so that there is no guarantee that the stated objectives can be achieved in accordance with the achievement of organizational standards. Development activities are designed in the concept of the Purwokerto IAIN strategic plan through the elaboration of the stages of the development target of Purwokerto IAIN in the next 5 years (2015 - 2019).

Becoming a Superior College in the Development of Science, Religion, and Culture in a National Context, Based on Islamic Values, in the Indonesian Socio-Cultural Context.

2) Becoming a State Islamic University that Has Good Governance To achieve these two targets.

Strategic plans cannot be separated from planning and budgeting activities that are oriented to the efficiency and effectiveness of financial performance and performance standards derived from the vision and mission of the IAIN. In this case, the problem is the extent to which the control system is carried out and is there a follow -up? Based on field data, the activity and financial reports have not been disclosed by the internal unit and by each leading sector submitted to the finance subdivision head and no review was conducted whether it was in accordance with the standard input costs (SBM) or not. This data can be used as evidence as one of the weaknesses of organizational control, so it can be said that the efficiency and effectiveness of the IAIN governance system have not been achieved, and there is no standardization of performance. According to freidenfelds [25], "It is also vital to carry over these strategic goals set in environmental policy to all the stakeholders - students, researchers and staff members and broader society". The policy on work systems in good stakeholder organizations, students, researchers and groups of employees will be able to encourage the achievement of higher education institution objectives, as evidence that the non-standard work target is that the Internal Control Unit has not been able to control all leading sectors, due to daily performance reports still manual and manipulation ranges [26].

Standardized performance built through the planning of the main performance indexes based online must be prioritized in building the quality of work within the IAIN environment throughout Indonesia. Based on interviews and observations, that the chancellors of IAIN in Indonesia did not yet seem to have a strong desire to realize the achievement of the implementation of Good University Governance based on the reality of organizational work governance that has not led to workgroups or team goals, organizational goals, and individual goals] Improvement of work in this context, needs to be measured through the development of knowledge, skills, capacities, competencies, and behaviors so that their performance can be known [27, $13]$.

\subsection{Planning in IAIN Financial Management}

IAIN in Indonesia has several leading sectors in its financial planning must refer to the regulations set by the Ministry of Religion. The financial planning standardization activities must be in accordance with the Input Cost Standards (SBM), for example in the 2018 budget, there has not been a joint review from each of the leading sectors. In February 2018 the Internal Supervisory Unit (SPI) of Purwokerto IAIN was formed and appointed by the Chancellor of IAIN, but the SPI and its members in 2018 were given the task by the Chancellor to prepare several SPI guidelines. The efforts carried out by SPI are working visits to several SPIs within the UIN, such as UIN Wali Songo, and UIN Sunan Ampel, then SPI assigns tasks to one team or SPI member to several national levels SPI forums, such as Bintek in UIN Walisongo Semarang and Bintek SPI at Sunan Ampel UIN. The Chancellor in the inauguration briefing of the SPI IAIN member in Purwokerto said that in relation to the SPI activities in 2018, at least it could prepare supervision implementation guidelines and map the absorption of budgets in each of the leading sectors.

Furthermore, the SPI IAIN Purwokerto in September at the Santika Purwokerto Hotel was involved in the review of SBM ceiling budget planning in 2019 with all the leading sectors. The budget planning of each leading sector is reviewed and adjusted to SBM in 2019. The results of the review include: Many details of the budget that must be revised by each leading sector both the terms of volume, units and amount of duties must be adjusted. In the context of SPI, its involvement provides experience and strengthening of audit systems and SPI as financial planning partners in improving financial planning systems and reporting systems that can be accounted for in accordance with applicable regulations.

In the context of the above activities, the Internal Audit Unit has a strategic role in carrying out its duties and authorities. The review of the 2014 RKAKL ceiling was proof of the importance of the audit system and audit incentives in the non-academic field. The implementation of the 2019 ceiling RKAKL review is useful for minimizing budget revisions and minimizing errors and fraud at the level of activity budget implementation. The direction of the review will be effective when the SPI can carry out its duties and functions. The performance approach strongly emphasizes the concept of value for money and oversight of output performance. That is, this approach is used to measure performance in achieving the goals and objectives of public services. The review activity can only classify accounts in the budget based on functions and activities as well as organizational units and details of expenditure, as well as revisions made by the leading sector.

The limitations of these activities have not led to activities aimed at investigating and measuring activities in order to obtain maximum efficiency and minimum cost standards. In addition, the allocation of funds optimally is based on the efficiency of the work unit and avoids waste. Obeying the law or rules is the foundation for building a work culture of a university, that regulation is a starting point for building a work culture in realizing the goals of organizational quality [28]. 


\subsection{Budget Work Planning}

The budget work plan is prepared by the leading sector in the IAIN environment based on the scope of needs and activity orientation. Furthermore, the amount of the budget is adjusted through work meetings and coordination meetings with the direction of the rector of IAIN Purwokerto and IAIN in general. In this activity, each leading sector conducts a more detailed discussion regarding the direction of the chancellor. Subsequent activities, the leading sector in the
IAIN formulated again and the revised results were submitted to the Planning Bureau. In the case of Purwokerto IAIN and generally, the 2018 budget year has not yet been reviewed about the Term of Referrals and RAB for each activity in the leading sectors based on the Input Cost Standards (SBM). like (see picture) that the five themes of GUG are not implemented in organizational governance, so that the effectiveness and efficiency of the organization cannot be evaluated which has proven by the data below:

Table 1. Faculty report.

\begin{tabular}{ll}
\hline Leading sector/faculty & Findings \\
\hline Education & Lack of support of data (report of sosialization and promotion, learning workshop activity, and practice activity) \\
Syari'a & Lack of support of data (report of rukyat, E-learning workshop, and concortium lecturer activity) \\
Da'wa & Lack of support of data (report of practice of field experience and capacity building) \\
Economi and Business & Lack of support of data (report of practice of field experience) \\
\hline
\end{tabular}

In the context of the research above, a program and budget allocation in the Budget Activity Plan (RKA) were carried out in SBM documents in each of the leading sectors (see Table.), examples of incomplete education faculty reports relating to table of contents, operating system procedures, attendance list of activity committees and curriculum vitae of participants. There are still many shortcomings to support organizational accountability, but the review has not been conducted analysis of program, activity, ceiling and performance target relationships between planning documents and budgeting feasibility. In addition, information requests are made regarding the principles and mechanisms, suitability, completeness, documentation, RKA drafting process, and incompatibility with the rules.

\subsection{Reporting System}

In managing work procedures in each State Islamic Religious Colleges (PTKIN) using the same standard, it is expected to produce uniform and comparable output between PTKIN, these expectations will encourage healthy competition in professional, transparent and accountable institutional governance according to with the vision of the Islamic Education Ministry of Religion of the Republic of Indonesia. This effort is nothing but to realize Good University Governance (GUG).

One of the efforts to improve organizational governance is through fostering and improving the quality of reports or non-academics at PTKIN by conducting a review of these financial statements. In the context of the review, IAIN Purwokerto, Pekalongan IAIN, and Tulung Agung IAIN or every leading sector for its activities have made financial reports. However, the actuality, planning, and RAB have not been reviewed for the Input Cost Benchmark (SBM) [29]. Unlike the Pekalongan Budget Plan (RAB), it was reviewed in advance and the financial reporting system and activities based on online. In addition, also in 2018, a review was conducted by the financial sector and the Internal Supervisory Unit (SPI) [26]. Based on a review in several PTKIN regarding the form to conduct a review of the RAB disbursement according to the rules established by each of the Internal Supervisory Units (SPI) [30].

Based on a review of one of the activities in 2018, the activity report was made by the Tadris Study Program IAIN Purwokerto about the seminar activities related to systematics and several attachments and completeness of the files in accordance with legislation and standard activity reports [31]. However, the seminar's financial report was not reviewed by the financial sector regarding budget implementation content with SBM budget ceiling 2018. As for the financial assessment with the conformity of the SBM in 2018, as follows: (a) In determining the volume adjusted for the needs of an activity. (b) Speak the committee according to the standard requirements, namely $10 \%$ of the total participants of the activity. (c) The word unit is replaced and adjusted to the unit (SBM) that has been determined. (d) The unit per item is in accordance with the applicable SBM. (e) The unit price of each budget detail in the shopping account, the honorarium for the activity, and the resource person is in accordance with the applicable SBM. (f) There is no uniformity in writing in each of the details. (g) The total amount in each account is better written in bold, so as to simplify the calculation of the total budget amount [30].

\subsection{Management of Human Resources}

Various managers or leaders of organizations struggle to realize their work programs. In that case, the leader to achieve the goals that have been formulated fulfillment of the goals that must be done. Challenges faced by organizations, functions of human resource management, the academic community and non-education personnel or employees. Failure to face these challenges will harm performance and even the organization or college. How important the goals of the organization are because it is useful to recognize human resource management that aims to contribute to the effectiveness of the organization [32].

In addition to organizational goals that must be considered, are functional targets. This functional objective aims to maintain the leading sector contribution that manages human resources at the level of organizational needs. Furthermore, social goals/teams provide awareness or responsiveness to 
various needs and demands of the community by minimizing negative impacts. Then another very important target, too, is the employee's personal goals. These individual goals aim to help employees achieve their goals, and function to improve organizational performance [33].

In the context of the Purwokerto IAIN strategic plan, that

"The program for improving the quality of human resources, facilities and management with a thorough, comprehensive and integrated planning policy with attention to the relevance of the focus of the development sector by considering the balance between activities and availability of resources (optimization is done by prioritizing the acquisition of national value-added prospective aspects starting from 2015 to 2016, continued on an ongoing basis) "[34].

This can be seen from the achievement of organizational performance that has been implemented based on the 2017 DIPA budget ceiling to obtain a budget ceiling of Rp.92,076,723,000 (Ninety-two billion seventy -six million seven hundred twenty- three rupiahs) [35]. From the activities that have been carried out with the attainment of input, output and outcome indicators averaging 96.7\%. Furthermore, the benefits and impact indicators after being evaluated have high harmony and effectiveness so that academic quality increases, so the measurement of performance achievement reaches $96.7 \%$ is in a good position. The qualifications are limited to qualitative and quantitative standard measurements have not been carried out as GUG standards.

\subsection{Management of State Property (BMN)}

If guarantees of good governance in the field of procurement of goods and services, as well as to contribute to the achievement of Good University Governance (GUG), then guidelines for examining the procurement of goods and services are needed. These guidelines are very important to be carried out in controlling, monitoring, and increasing efficiency and effectiveness in obtaining goods and services. In getting good goods and services in accordance with the plan, there is a need for guidance on inspection of procurement of goods/services as a reference within the State Religious College (PTKIN) especially IAIN Purwokerto.

Based on observations in the field there are findings of several matters relating to the management of state property, as follows: in general ULP also has a general purpose, has carried out checks and documentation in accordance with the Accounting Decision Letter of Goods User Power (UKPB) as follows: Check and document, semester/ annual reporting, BMN control, follow up on audit results, Property User Authorization (UKPB) accounting has not carried out an inventory in accordance with the SOP, Goods User Authorization (UKPB) accounting has planned BMN needs every year, maintenance planning and documentation ownership but there are several BMNs that have not yet been recorded in SIMAK-BMN, but the Property User Proxy accounting (UKPB) in terms of planning, security and BMN maintenance is in accordance with the applicable provisions [36].

\section{Conclusions}

This study produced several findings that Purwokerto IAIN and others had implemented gradually the principles of the Good University Government. However, departing from the three financial reporting spaces, human resource management, and State Property (BMN) management, that these three fields still have many weaknesses both in the planning system and in the control in each of the leading sectors. The review system is carried out at both the planning and budget submission levels, as well as reviewing activity reports as an urgent need as an effort to prevent and guarantee the organization's health.

Departing from several weaknesses in managing the three fields mentioned above, it will affect the efficiency and effectiveness of the performance and objectives of the organization or governance of the organization of Islamic religious institutions. Therefore, this study recommends an internet-based governance system that refers to the main performance leaders of higher education institutions. In addition, standard management guidelines for reporting systems are needed, standard HR's management guidelines, and BMN management standards guidelines.

\section{References}

[1] Ibnu Purna., Hamidi., Prima., "Perekonomian Indonesia Tahun 2008 Tengah Krisis Keuangan Global," 12-Nov-2013.

[2] Sri Mulyani, "Menkeu: 10 Tahun Terakhir Pertumbuhan Ekonomi Cukup Baik,” Jakarta, 2017.

[3] Tjager, I. N., Alijoyo. F. A dan Djemat, H. R., Soembodo. B, Corporate Governance: tantangan dan kesempatan bagi komunitas bisnis Indonesia. Forum Corporate Governance in Indonesia (FCGI). Jakarta: Ikrar Mandiriabadi, 2003.

[4] Sakina Rakhma Diah Setiawan, "Daya Saing Indonesia Kalah Dibanding Negara-negara Tetangga," Kompas.com, 17-Okt-2018.

[5] Fama, E., "Agency problem and the theory of the business," $J$. Polit. Econ., vol. 88, 145 134M.

[6] Wijatno, S., Pengelolaan Perguruan Tinggi Secara Efisien, Efektif dan Ekonomis. Jakarta: Salemba Empat, 2009.

[7] Puput Tripeni Juniman, "Peringkat Perguruan Tinggi Indonesia di Dunia Merosot," CNN Indonesia, 21-Jun-2018.

[8] Kodrat Setiawan Ed., "Cuma 3 PTN RI Masuk 500 Besar Dunia, Jokowi Sentil Kemenristek,” Tempo.co, 21-Des-2018.

[9] Tillar, H. A. R. dan Riant, Nugroho., Kebijakan Pendidikan. Yogyakarta: Pustaka pelajar, 2009.

[10] J. Milliken dan G. Colohan, "Quality or Control? Management in Higher Education," J. High. Educ. Policy Manag., vol. 26, no. 3, hlm. 381-391, Nov 2004.

[11] A. Saiti, "Leadership and quality management: An analysis of three key features of the Greek education system," Qual. Assur. Educ., vol. 20, no. 2, hlm. 110-138, Apr 2012.

[12] E. Sallis, Total Quality Management in Education, 3 ed. Kogan Page, 2002. 
[13] Mary Wambui Kathombe, Simon Kipchumba, dan Kibet Kirui, "Reward Management Strategies and Employee Performance in Selected Universities in Nakuru County, Kenya," J. Hum. Resour. Manag., vol. 6, no. 3, hlm. 95-102, 2018.

[14] Martin, Judith N., dan Nakayama, Thomas K., Intercultural Communcation in Contexts. New York: McGraw-Hill, 2010.

[15] Jamie frueh, Political identity and social change. Albany: state university of new york press, 2003.

[16] T. E. H. Mark D. Nelson, Applied Organizational Communication: theory and practice in global enviroment, 3 ed. London: Lawrence Erlbaum Associates, 2008.

[17] Darmawati, D., Khomsiyah dan Rahayu, R. K., "Hubungan Corporate Governance dan Kinerja Perusahaan," Simp. Nas. Akunt. VII, 2004.

[18] Schmidtlein, F. A, A review of literature on higher educational institutional planning. Washington DC: National Centre for Postsecondary Governance and Finance, US Department of Education, 1990.

[19] D. Lesjak, "Improving Higher Education (Institutions) with the Matrix of Managerial and Financial Objectives," Procedia - Soc. Behav. Sci., vol. 238, hlm. 249 - 258, 2018.

[20] Burhan Bungin (terakhir), Sosiologi Komunikasi, 3 ed. Jakarta: Kencana, 2008.

[21] Moleong, Lexy, Metodologi Penelitian Kualitatif. Bandung: Remaja Rosda Karya, 2000.

[22] D. freidenfelds, S. N. Kalkins, dan J. gusga, "What does environmentally sustainable higher education institution meaan?," Elsevier, hlm. 43-45, 2018.

[23] Kepala SPI IAIN Purwokerto, Kepala SPI IAIN Cirebon, Kepala SPI IAIN Pekalongan, dan Kepala SPI IAIN Tulung Agung, "Kinerja leading sektor IAIN di Indonesia," 09-Sep2018 .

[24] Siu, O. 1., $d k k$., "Role resources and work-family enrichment: The role of work engagement," Ournal Vocat. Behav., vol. 77, no. 3, hlm. 470-480, 2010.

[25] A. Ernest Osseo - Asare dan D. Longbottom, "The need for education and training in the use of the EFQM model for quality management in UK higher education institutions," Qual. Assur. Educ., vol. 10, hlm. 26-36, Mar 2002.

[26] Kasubag keuangan IAIN Purwokerto, "Laporan Kinerja Keuangan,” 11-Okt-2018.

[27] SPI IAIN Purwokerto, Hasil review ini didasarkan pada SBM. Purwokerto, 2018.

[28] Peraturan Menteri Keuangan, "Peraturan Menteri Keuangan Nomor: 255/PMK.05/2015, tentang, Standar Reviu Laporan Keuangan.” 2015.

[29] Geoffrey D. Doherty Ed., Developing quality systems in education, 1 ed. London: Routledge, 1994.

[30] Justine Mercer Bernard Barker dan Richard Bird, Human Resource Management in Education Contexts, themes and impact. London: Routladge, 2010.

[31] “Rencana Strategis IAIN Purwokerto 2015 - 2019.” 2018.
[32] "Laporan Akuntabilitas Kinerja Pemerintah (LAKIP) Tahun 2017 IAIN Purwokerto," 2017.

[33] Itjen dan SPI, hasil temuan Irjen dan pendampingan ke ULP. Purwokerto, 2018.

[34] Ibnu Purna., Hamidi., Prima., "Perekonomian Indonesia Tahun 2008 Tengah Krisis Keuangan Global," 12-Nov-2013.

[35] Sri Mulyani, "Menkeu: 10 Tahun Terakhir Pertumbuhan Ekonomi Cukup Baik,” Jakarta, 2017.

[36] Tjager, I. N., Alijoyo. F. A dan Djemat, H. R., Soembodo. B, Corporate Governance: tantangan dan kesempatan bagi komunitas bisnis Indonesia. Forum Corporate Governance in Indonesia (FCGI). Jakarta: Ikrar Mandiriabadi, 2003.

[37] Sakina Rakhma Diah Setiawan, "Daya Saing Indonesia Kalah Dibanding Negara-negara Tetangga," Kompas.com, 17-Okt-2018.

[38] Fama, E., "Agency problem and the theory of the business," $J$. Polit. Econ., vol. 88, 145 134M.

[39] Wijatno, S., Pengelolaan Perguruan Tinggi Secara Efisien, Efektif dan Ekonomis. Jakarta: Salemba Empat, 2009.

[40] Puput Tripeni Juniman, "Peringkat Perguruan Tinggi Indonesia di Dunia Merosot," CNN Indonesia, 21-Jun-2018.

[41] Kodrat Setiawan Ed., "Cuma 3 PTN RI Masuk 500 Besar Dunia, Jokowi Sentil Kemenristek,” Tempo.co, 21-Des-2018.

[42] Tillar, H. A. R. dan Riant, Nugroho., Kebijakan Pendidikan. Yogyakarta: Pustaka pelajar, 2009.

[43] J. Milliken dan G. Colohan, "Quality or Control? Management in Higher Education," J. High. Educ. Policy Manag., vol. 26, no. 3, hlm. 381-391, Nov 2004.

[44] A. Saiti, "Leadership and quality management: An analysis of three key features of the Greek education system," Qual. Assur. Educ., vol. 20, no. 2, hlm. 110-138, Apr 2012.

[45] E. Sallis, Total Quality Management in Education, 3 ed. Kogan Page, 2002.

[46] Mary Wambui Kathombe, Simon Kipchumba, dan Kibet Kirui, "Reward Management Strategies and Employee Performance in Selected Universities in Nakuru County, Kenya," J. Hum. Resour. Manag., vol. 6, no. 3, hlm. 95-102, 2018.

[47] Martin, Judith N., dan Nakayama, Thomas K., Intercultural Communcation in Contexts. New York: McGraw-Hill, 2010.

[48] Jamie frueh, Political identity and social change. Albany: state university of new york press, 2003.

[49] T. E. H. Mark D. Nelson, Applied Organizational Communication: theory and practice in global enviroment, 3 ed. London: Lawrence Erlbaum Associates, 2008.

[50] M. Thoha, Perilaku Organisasi: Konsep Dasar dan Aplikasinya, 2 ed. Jakarta: CV. Rajawali, 1986.

[51] Darmawati, D., Khomsiyah dan Rahayu, R. K., "Hubungan Corporate Governance dan Kinerja Perusahaan," Simp. Nas. Akunt. VII, 2004.

[52] Schmidtlein, F. A, A review of literature on higher educational institutional planning. Washington DC: National Centre for Postsecondary Governance and Finance, US Department of Education, 1990. 
[53] D. Lesjak, "Improving Higher Education (Institutions) with the Matrix of Managerial and Financial Objectives," Procedia - Soc. Behav. Sci., vol. 238, hlm. 249 - 258, 2018.

[54] Burhan Bungin (terakhir), Sosiologi Komunikasi, 3 ed. Jakarta: Kencana, 2008.

[55] Moleong, Lexy, Metodologi Penelitian Kualitatif. Bandung: Remaja Rosda Karya, 2000.

[56] Kasubag Fakultas FTIK, "Persoalan kepemimpinan di IAIN," Agu-2018.

[57] Idowu Owoeye dan Stephen Makau Muathe, "CompetenceEnhancing Interventions and Organisational Performance: A Theoretical Review," J. Hum. Resour. Manag., vol. 6, no. 2, hlm. 67-77, 2018.

[58] D. freidenfelds, S. N. Kalkins, dan J. gusga, "What does environmentally sustainable higher education institution meaan?," Elsevier, hlm. 43-45, 2018.

[59] Kepala SPI IAIN Purwokerto, Kepala SPI IAIN Cirebon, Kepala SPI IAIN Pekalongan, dan Kepala SPI IAIN Tulung Agung, "Kinerja leading sektor IAIN di Indonesia," 09-Sep2018.

[60] Siu, O. L., $d k k$., "Role resources and work-family enrichment: The role of work engagement," Ournal Vocat. Behav., vol. 77, no. 3, hlm. 470-480, 2010.
[61] A. Ernest Osseo - Asare dan D. Longbottom, "The need for education and training in the use of the EFQM model for quality management in UK higher education institutions," Qual. Assur. Educ., vol. 10, hlm. 26-36, Mar 2002.

[62] Kasubag keuangan IAIN Purwokerto, "Laporan Kinerja Keuangan," 11-Okt-2018.

[63] SPI IAIN Purwokerto, Hasil review ini didasarkan pada SBM. Purwokerto, 2018.

[64] Peraturan Menteri Keuangan, "Peraturan Menteri Keuangan Nomor: 255/PMK.05/2015, tentang, Standar Reviu Laporan Keuangan.” 2015.

[65] Geoffrey D. Doherty Ed., Developing quality systems in education, 1 ed. London: Routledge, 1994.

[66] Justine Mercer Bernard Barker dan Richard Bird, Human Resource Management in Education Contexts, themes and impact. London: Routladge, 2010.

[67] “Rencana Strategis IAIN Purwokerto 2015 - 2019.” 2018.

[68] "Laporan Akuntabilitas Kinerja Pemerintah (LAKIP) Tahun 2017 IAIN Purwokerto," 2017.

[69] Itjen dan SPI, hasil temuan Irjen dan pendampingan ke ULP. Purwokerto, 2018. 